システム制御情報学会論文誌, 4 巻, 7 号, pp. 259 266 (1991)

複雑な構造をした非線形システムの同定を目的 としたニューラルネットワーク

近藤 正

本研究では, 構造が複雑でしかもその物理構造がよく わからない非線形システムの同定問題に対して, 対象シ ステムから得られる入出力データを用いて学習を絽り返 すととにより，そのシステムの特徴をネットワークの内 部に記憶保存させることができるニューラルネットワー クを構成し，従来から用いられてきた統計的非線形シス テム同定手法（GMDH 手法）との比較を行ない，その 有効性を明らかにする.

システム制御情報学会論文誌, 4 巻, 7 号, pp. 267〜276 (1991)

\section{定性ネットワークモデルとそのシミュレーショ ンアルゴリズム}

堂園 浩・石田 好輝・得丸 英勝

プラントなどの大規模物理系に対する，定性シミュレ ーションアルゴリズムを開発した.プラントのような大 規模物理系においては, 状態変数が多く複雑に作用しあ うため, 数值的なシミュレーションは不可能であったり, 数式に基づくモデルが得られない場合がある. そのため, 本論文では，変数間の作用関係をアークとする定性ネッ トワークモデルを用い, ネットワーク上での定性シミュ レーションについて考察した，そのアルゴリズムは基本 的には deKleerのアルゴリズムを定性ネットワーク上 で応用したもので次に述べる特徴を持つ.（1）值伝播を 静的伝播と動的伝播に分けることで定性シミュレーショ ンに特徴的な分岐の数を減らした.（2）静的伝播に伴う 決定不能な变数と発生をバランス機能により抑えた.（3） ネットワーク上で一貫性を保ちながら值伝播を行なうて とができる.

システム制御情報学会論文誌, 4 巻, 7 号 pp 277〜285 (1991)

\section{制御を前提とした設計手法とその車両操舵機構 への応用}

\section{河辺 徹・得丸 英勝}

機械システムの設計において，従来行なわれている手 順では, 制御性からの要求により機械要素の值を決定で きないという点に問題があると思われる，そこで，制御 を前提として機械システムを設計する手法を提案する.
本手法では，機械設計に対する評価規範として，入力偏 差による評価を行ない, この結果と制約条件に基づいて 機械要素の值などを決定する.さうに，乙の手法を自動 車の操舵システムの設計に応用した。

システム制御情報学会論文誌, 4 巻, 7 号 pp. 286〜293 (1991)

\section{拡散需要を伴う生産管理システムの最適制御}

土肥 正・海生 直人・尾崎 俊治

従来の生産管理システムに関する多くの研究は, 不確 実性下での需要量を時間と独立な確率変数として取り扱っ てきた。これに対し，本論文では需要量が Markov 拡 散過程に従う場合の生産管理システムについて議論する. 最適生産量を解析的に導出する手法として, 確率制御の 手法が用いられる，本論文の主な目的は，従来の決定論 的モデルを確率場に拡張し, さらに需要分布の形状の違 いによる生産管理システムの制御特性を明確に示すとと である.

システム制御情報学会論文誌 4 巻, 7 号, pp. 294〜301 (1991) 協力環境下での学習オートマトンの集団モデル 銭飛・平田 廣則

複数の目標が存在する最適制御においては, 制御シス テムは，乙れらの目標の実現を目指す複数の制御者から なる．複数の制約条件のもとで環境の変動が事前に予知 できない場合に，競争的あるいは協力的に共存している 各々の制御者が，ある種の集団行動を形成する現象は社 会システム，経済システムなどの中でよく見られる．ゲ 一ム理論の立場から見れば，乙のようなシステムは協力, 非協力ゲームに帰着される.

本研究では，てのような複数の目標のあとで動作して いるシステムの最適化問題を取り上げ, 複数の静的なラ ンダム環境 (教師) 下で動作している学習オートマトン の集団モデルについて考察し，モデルの定義，評価基準 などを与え，ランダム環境に適応するための各オートマ トンの強化法の構築方法を示す.

集団モデルとしては，種々のタイプが考えられるが， 本文では，とくに，協力環境下での非協力ゲームのモデ ルについて考察し，乙のモデルの静特性および動特性を 議論したうえで $P$-model と $S$-model の二つのタイプ の学習オートマトンに対応できる強化法を提案する. ま た, 強化法の収束性の評明を与え, 簡単なシミュレーショ ン例を用いて，それを検証する。 


\title{
定性ネットワークモデルとそのシミュレーション アルゴリズム*
}

\author{
堂園 浩 ${ }^{* *}$ - 石田好輝 ${ }^{* * *}$. 得丸英勝 ${ }^{* * * *}$
}

\section{On the Simulation Algorithm for Qualitative Network Model*}

\author{
Hiroshi Douzono**, Yoshiteru Ishida ${ }^{* * *}$ and Hidekatsu ToKumaru ${ }^{* * * *}$
}

\begin{abstract}
We propose an algorithm for qualitative simulation of the large scaled physical systems such as plants. Such systems are often complicated for numerical simulation, thus the qualitative simulation is often used for analysis. We use the qualitative network model and implement a simulation algorithm modified for the qualitative network. This algorithm has three important futures: (1) devision of the propagation into two types, dynamic propagation and static propagations (2) balancing mechanism to avoid the undefined values, (3) rules for keeping consistencies on the network model.
\end{abstract}

\section{1. 緒 言}

物理系などの解析の手法の一つとして定性シミュレー ションと呼ばれる方法がある. 定性シミュレーションと は物理系を定性的な知識表現によるモデルで作成し, シ ミュレーションを進めて行くことで物理系の解析を行な

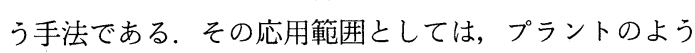
な大規模な物理系を解析し, 故障診断のための知識を獲 得するなどが考えられる1). プラントの解析を定量的な 方法で行なう場合, 多数の状態变数が作用しあうため, 複雑な微分方程式の系を扱わなければならない，また， 状態変数間の関係が正確な微分方程式として得られない 場合もあり, 定量的な方法では解析が困難になる。 そこ で，定性的なモデルを用いて，簡単な記号的処理のみに よりシミュレーションを行なう方法が有効になる。 また, シミュレーションのモデルの獲得の点でも, 正確な数式 モデルが必要でないため, より簡単になる.

定性シミュレーションに関する研究に扔いて，そのモ デルの記述法は, 知識の記述性, およびシミュレーショ ンの実行法に重要な関わりを持つ.これまで行なわれて

* 原稿受付 1990.5.14

** 熊本大学 工学部 Kumamoto University, 2-39-1, Kurokami, Kumamoto-city 860, JAPAN

*** 京都大学 工学部 Kyoto University, Yoshidahonmachi, Sakyo-ku, Kyoto 606, JAPAN

***** 京都大学 工学部 (現, 立命館大学 理工学部)

Key Words : qualitative reasoning, physical model, plant model, qualitative simulation, knowledge engineering.
きた研究では，主に定性方程式が記述モデルとして用い られてきた ${ }^{2)}$.この方法では, 実際の数值を扱う方程式 を変換して定性方程式を作成するため, シミュレーショ ンの対象が方程式として記述されている必要がある.し かし, 前に述べたようにプラント等の大規模な系では, 対象の方程式を得ることは難しい場合がある。また，方 程式自身が，プラントの構造と直接に結び付いているの ではなく，プラント全体を物理系として表わすすのであ るため, プラントの構造的知識がら直接に, 方程式のモ デルを得ることは困難である. そこで, 本研究では, 定 性ネットワークモデルを用い, その構成とネットワーク 上での定性シミュレーションについて考察した，定性ネッ トワークモデルは，モデル化対象に含まれる変数をノ一 ドとし，その間の物理的な作用をアークで表現したあの で, 定性方程式よりプラントなどの物理的な構造に近く, 直感的なモデルの構築が可能である. また, 実際のモデ ル構築にはオブジェクト指向アプローチに基づく記述言 語を用意しており，モデルの記述性を高めている，ただ し，ここで扱う定性ネットワークは，主に線型のシステ ムをモデル化の対象とし, 一部の非線型要素の記述も可 能なものとする.

本論文で扱う定性シミュレーションは, 解析対象とす るシステムの外乱に対する状態変化の解析を目的とする. つまり，ネットワークでモデルを表現し，ネットワーク 上で外乱を前向きに值伝播を行なうことでシミュレーショ ンを進めていく，ここで, 值伝播を線型なすのに限ると, 
值伝播はある変数における時間的な值変化を表わす動的 伝播と, その変化にともなう他の変数の值変化をあらわ す静的伝播に分けて処理が可能であり, 時間的な状態変 化をおこす動的伝播の選択の方法が単純になる。また, 非線型な伝播に関しては, 決定可能な值のみ伝播させ ることで部分的に表現し, 值の収束などの特殊な場合 のみ検出するすのとする. 従来の方法と比較すると, Kuipers (1983) ${ }^{4)}$ の定性シミュレーションの方法では, 本論文の方法と同じくネットワーク上での伝播を用いシ ミュレーションを行なうあのであるが，モデル構築の手 法, シミュレーションの方法は異なる部分が多い，また， このアルゴリズムでは, 定性值の物理的な一貫性を保つ ために, deKleer (1984) の方法で用いられている規則 をネットワーク上のシミュレーションのために応用した あのを用いている. また, 本研究で作成したシステムで はオブジェクト指向アプローチに基づき各部分ごとにモ デルを作成し，それを結合させて全体を構成する枠組み を用意している．そのための結合時の伝播規則に対する 考察も行なった。

本論文では 2. で，モデル化に用いる定性ネットワー クを, 3. でそのシミュレーションの方法の概略を述べる. そして，4. ではネットワークの一貫性まで考えたシミュ レーションについて述べ，5.で deKleer, Kuipers の 方法との比較を行ない，6. で例題を示す.

\section{2. 定性ネットワークモデル}

定性ネットワークでは対象之なるシステムの各状態変 数をネットワークのノードで，变数間の物理的な関係を アークで表わすものとする．ただし，すべての変数はあ る一点の值を基準值として持ち, すべての変数が基準值 にあるとき, またその時に限り, そのシステムは定常状 態にあるあのとする.

フロー構造を表わす基本モデルでは変数はその主值と 1 階から $n$ 階までの微分值を，次のように定性的な形 式で持つ.

0 值が 0 あるいは基準值

+ 值が正あるいは基準值より大

- 值が負あるいは基準值より小

? 值が決定不能

ただし， 0 は值が 0 あるいは基準值の 1 点を表わすすの とし，ある領域を持つようなるのは扱わない，また，階 数については理論上の制限はないが, 試作したシミュレ 一夕では，4階の微分值まで計算に用い，2 階の值まで を表示するものとした．これは，モデルの変数值，変数 の変化の状態，およびグラフの凹凸までを検出すること を考えると 2 階微分值まで必要であり， 2 階微分值まで
正確に求めるには，4階微分値ぐらいまで必要であると 考えたためである.

变数の值は, 主値, 1 階微分値, 2 階微分値のように, 順に並べたベクトル形式で，次のように表記する.

FlowIn $=(0,+,-,+)$ アークは変数間の物理作用を表わし，次のような属性を あたえる。

(1) 作用の種類

(1) 線型に正の作用 + 線型に負の作用 -

(2) 值が等しい=

(3) 入力の值がすべて 0 のときのみ 0 を伝播し，その他 の場合は決定不能 ?

(4) 值の絶対值 (負の絶対値) を伝播 $++(--)$

(3), (4) は線型の作用 $(+,-)$ のみでは表現できない非 線型の作用を表わすのに用いる.

また，作用の種類は；変数のすべての階数に対して共 通に与える場合之, 各微分階数に別々に与える場合があ り，基本的には，線形の作用の場合はすべての階数間で 共通とし，非線形の場合は別々に与える。これは，定性 方程式において，線形のシステムを表わす式は何度微分 しても, 同じ階数差を持つ変数間の関係は変化しないが, 非線形の場合には，式の変形が起こり階数差のみでは関 係が定義できないためである.

（2）階数差 入力の変数から出力の変数への作用の微分 值の階数の差を整数值で与える．ただし，今回作成した システムでは变数の微分階数は 4 階までなので， あまり 大きな数は意味がなく，2 階差ぐらいまでが適当である.

実際のモデル作成の例を示す．まず，系の微分方程式 が得られる場合には，微分方程式に現れる変数および微 分值間の関係をそのまま定性ネットワーク变換する．次 の方程式に対しては，Fig.1のようなネットワークが 作成される.

$$
\begin{aligned}
& a \cdot \frac{d^{2} x}{d t^{2}}+b \cdot \frac{d x}{d t}+c \cdot x=y \\
& (\text { ただし, } a>0, b>0, c>0)
\end{aligned}
$$

まず，微分階数が最大の要素（この場合は $d^{2} x / d t^{2}$ ) に 注目し，それに関する他の要素からの作用をアークで 記述する。ここでは， $d x / d t$ からの作用が階数差 1 で 負の作用 (arc 1), $x$ からの作用が階数差 2 で負の作用

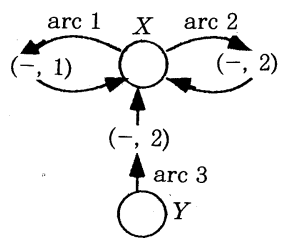

Fig. 1 Qualitative network for sample equation 
$(\operatorname{arc} 2), y$ からの作用が階数差 2 で正の作用 (arc 3) と なる.

微分方程式を用いずに，物理モデルから直接に作成す る場合は, アークを用いて物理系の各変数の関係を記述 していく，例としては, Fig. 2 (1) のようなタンクの モデルについて定性モデルを作成するあのとする．まず, 変数としてはパイプからの流入量 FlowIn, タンクの水 位 Level, タンクからの流出量 FlowOut が考えられる. それぞれの変数間の作用について考察すると, 流入量 はタンクの水位を増加させるが，水位は積分として現れ るので, FlowIn から Level へ階数差 1 で正の作用, 同 じく流出量は減少させるので FlowOut から Level へ階 数差 1 で負の作用となる．また，水位が上がると流出量 はほぼ比例して増えると考えられるので, Level から FlowOutへの正の作用とし, Fig. 2 (2) のようなモデ ルが得られる。ここでさらに, Level とFlowOutの間 の関係として，次の式が得られたとする.

FlowOut $=a \cdot(\text { Level }+b)^{1 / 2}$

この式は FlowOut と Level の主值間の関係を表わして いる.この場合, 非線型要素 $\sqrt{ }$ が含まれるため, 微分值に関しては別に関係を求める必要がある.

$$
\begin{aligned}
& d \text { FlowOut } / d t=a / 2 \cdot(\text { Level }+b)^{-1 / 2} \cdot d \text { Level } / d t \\
& \begin{aligned}
d^{2} \text { FlowOut } / d t^{2} \\
=-a / 4 \cdot(\text { level }+b)^{-3 / 2} \cdot(d \text { Level } / d t)^{2} \\
\quad+a / 2 \cdot(\text { Level }+b)^{-1 / 2} \cdot d^{2} \text { level } / d t^{2}
\end{aligned}
\end{aligned}
$$

$(L e v e 1+b)$ の符号変化はないので, 1 階微分值間は正 の作用, FlowOutの 2 階微分值へは Level の 1 階微分 值から絶対值で負の作用, Levelの 2 階微分值からは正

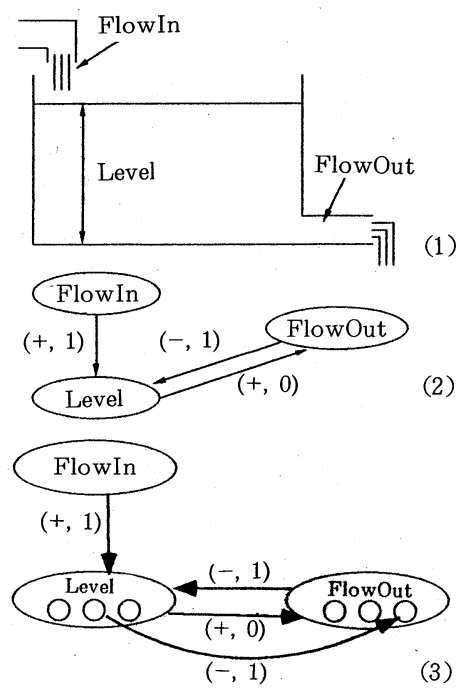

Fig. 2 Qualitative network model for buffer tank
の作用となり，Fig.2（3）のモデルが得られる．ただ し, 変数内の小円はそれぞれ主值および微分值を表わす. このモデルは，乙の系に対する次の方程式から作成した ものと一致する.

$$
\begin{aligned}
& d \text { Level } / d t=c \cdot(\text { FlowIn }- \text { FlowOut }) \\
& \text { FlowOut }=a \cdot(\text { Level }+b)^{1 / 2}
\end{aligned}
$$

このように定性ネットワークモデルは系の微分方程式 から，あるいは，系の持つ変数間の物理的な関係の記述 の両方から作成することができるが，本論文が目的とす るモデル化の方法は主に後者の方法である，つまり，プ ラントなどの物理系に対し, まず, 基本的な要素（タン ク，パイプなど）のモデルを作成する.この段階では, ある程度は微分方程式などあ利用できるため, 微分方程 式加定性ネットワークを作成することも考えられる. しかし，実際の要素は基本的なものばかりではないので, つぎに，そのモデルを基に，種々の作用を行なう変数, アークを加えることで, 実際のプラントに存在する要素 に対応するモデルを作成する．この段階では，定性方程 式よりあ定性ネットワークの方が直感的にわかりやすく, 記述が容易になる。 そして，それらを結合し組み合わせ ることで全体のモデルを作成する．このようなモデル化 においては, 方程式による記述よりあ, 定性ネットワー クモデルの方が，むいていると考えられる.

また，実際に作成したシステムでは，定性值に関して は大きさのオーダー付けによる表現，領域を持つ基準值 の処理, 作用アークに関しては, 作用の優先度, 作用の 大きさのオーダー付け，作用の伝播の遅れ時間の表現な どを含むものであるが，本論文では触れない.

ここで, 定性ネットワークモデルのモデルに対する条 件をまとめておく．（1）基本的には線形のシステムであ り, 一部にのみ非線形の部分を含む,，(2) モデルは変数 間の作用をアークで表わしたものを用いる，(3) 各变数 は 1 点の值を基準值として持ち，すべての変数が基準值 の時，かつその時に限りシステムは定常状態にある.

次節以降では, このような定性ネットワークモデルに おける定性シミュレーションのアルゴリズムについて述 ベる.

\section{3. 定性シミュレーション}

定性ネットワークは, すべての定性值が 0 の時には定 常状態である. 本論文で対象とする定性シミュレーショ ンは，その定常状態に対し何らかの外乱を加え，その全 体への伝播の状況および収束の可能性などを解析するも のである.この章以降でその值伝播のアルゴリズムにつ いて述べる. 


\section{1 基本伝播規則}

定性ネットワークに対して, ある変数に外乱を加え, その值を伝播させることで定性シミュレーションが行な われる. 定性ネットワーク上の值伝播は, 値をアークに より伝播させる静的伝播と, 変数内の值の動的な変化を 扱う動的伝播に伝播を分けられる. 動的伝播は系の時間 変化を発生させるむので, 実際にはいずれかの微分值を その一階下の值の変化方向として伝播を行ない, 変化に 時間を要するものと時間を必要としないものがある. 静 的伝播は, 初期值の設定や動的伝播の発生に伴う変数 （微分值む含む）の值変化を, 他の変数に伝播させるも ので, 実際にはネットワークのアークで結合された変数 （自分自身の場合あある）に対し，同じ階数の值あるい はより高階の微分值の変化として処理される. また, 静 的伝播はアークで結合された複数の変数および微分值の 同時変化を表わすあのであり, 変化に時間を必要としな い. 全体的には, 動的伝播が状態変化を起こす引き金と なり，静的伝播で全体のバランスをとるということにな る. 定性シミュレーションは, 動的伝播とそれに伴う静 的伝播, および, それらの值变化に伴う動的伝播の検出 を繰り返し実行することで, 進められる. 次にそれらの 実行について述べる.

\section{（1）静的伝播}

静的伝播は次の静的伝播規則により実行される.

\section{(a) 静的伝播規則}

ある变数において $n$ 階 $(n>=0)$ の值が変化したと き, 次の静的伝播規則により伝播を行なう.

(a-1) 作用が+のアークに対しては, その值をそのま ま出力側の変数へ伝播し, 作用方向がーの時は, 符号を 反転して伝播する．作用が++ (- - ) のアークに対し ては, その入力の (負の) 絶対值の伝播を行なう。作用 が?のアークに対しては, 值 0 の時のみ 0 をそうでない 場合は? ?伝播する.ただし, 值? を伝播する場合はよ゙ のようなアークの場合であ， ?が伝播される.

(a-2) 階数差は, 階数差の分だけ伝播させる変数の階 数を增やして伝播する. つまり, 階数差が $m$ の時は, 出力側の変数の $n+m$ 階の值に伝播される.

(a-3) 変数への入力アークが一つのみのときは, その アークにより伝播された值が, そのまま変数値になる.

変数が複数の入カアークを持つときは，その值はすべ てのアークにより伝播される值の和となる．定性値の 和の值は, Table. 1 に基づく定性演算により決定され る.

(a-2)において, 階数差が 0 でない場合は主値から微 分值, あるいは, 微分值からより高階の微分值への伝播 が行なわれ，次に述べる動的伝播の発生源となる。
Table 1 Qualitative addition $A+B$

\begin{tabular}{|c|c|c|c|c|}
\hline$A \quad B$ & - & 0 & + & $?$ \\
\hline- & - & - & $?$ & $?$ \\
\hline 0 & - & 0 & + & ? \\
\hline+ & ? & + & + & ? \\
\hline$?$ & $?$ & ? & ? & $?$ \\
\hline
\end{tabular}

\section{（2）動的伝播}

微分值はその一つ低階の值の変化量になるため, その 值が定量值におけるしきい值に達した時, 定性值に変化 を起こす．たとえば, $V=(+,-, 0)$ の場合, 1 階の值 “-”が主值（0階）の “+”に減少の作用をし， $V=(0$, $-, 0)$ となり, さらに $V=(-,-, 0)$ と変化する. 動的 伝播は次の動的伝播規則により処理される.

\section{(b) 動的伝播規則}

(b-1) 動的伝播が発生すると定性值が,,$+- \quad$ ? の微 分值は, 一つ低階の值に同じ方向の作用を行なう。 その 作用結果は Table 2 に従う.

Table 2 Dynamic propagation

\begin{tabular}{|c|c|c|c|}
\hline$x$ & - & + & $?$ \\
\hline- & - & 0 & $?$ \\
\hline 0 & - & + & $?$ \\
\hline+ & 0 & + & $?$ \\
\hline$?$ & $?$ & $?$ & $?$ \\
\hline
\end{tabular}

(b-2) 動的伝播の際に変化した值は, 変化直後に静的 伝播を行ない, 他の変数を変化させる.

ただし, 微分值の值が 0 以外の值であっても, 必ずしも 次のステップで Table 2 に定義された動的伝播が発生 するとは限らず, 次ステップで必ず Table 2 で示す值 になるという意味でもない，これは，後に述べるネット ワークの一貫性などの条件により, 発生可能な動的伝播 が限定されるからである. (b-2)の処理により, 結合 された複数の变数において同時に発生すべき值变化を一 つの動的伝播からの静的伝播により実行する.

また, 定性值,,+- 0 の中で 0 のみが 1 点を表わす という特異性から次の規則が成り立つ.

(c) 0 の瞬時性 (instant change rule)

定性値 0 一動的伝播は, 同じ微分值からの作用により, 定性值 0 は瞬時で通過する.つまり, 定性值 0 は 1 点の 值を表わすため一つ高階の微分值が 0 でない場合は, そ の作用により 0 から移動することになる。 
実際には，0 を静的伝播させた直後に動的伝播を繰り返 し，0点を通過させる. ただし $(b-2)$ を用いて，0の静 的伝播により微分值が变化し, 動的伝播が発生しない場 合あある.

動的伝播は, 微分值が 0 でないすべての変数で発生す る可能性があるが，それらはすべて独立ではない，その ため次の規則で独立に発生できる動的伝播を決定し，そ れに従属する動的伝播は静的伝播で処理するものとする.

\section{(d) 動的伝播発生の決定則}

次の (1), (2),（3）の三つの場合に, 独立な動的伝播 が新たに発生する.

（1）静的伝播によりフローの合流点において, 微分值が 0 以外の値に変化した場合

（2） 0 階の值からの静的伝播により微分值が 0 以外の值 に変化した場合

（3）上位オーダの微分值からの動的伝播により微分值が 0 以外の值に変化した場合

これらの規則は最も基本となる伝播規則でありこれら のみでは静的伝播における + , 一 の競合が多数発生し 決定不能の変数が多くなってしまう。 そのため次節にの べる動的バランス則を付け加える.

\section{2 動的バランス則}

動的バランス則は, 動的伝播発生の決定則の拡張で, 変数に入力される定性值の大きさのバランスを考えて, 動的伝播を発生させるものである．動的伝播にともなう 静的伝播により? が発生した状態の例を Fig. 3 に示す.

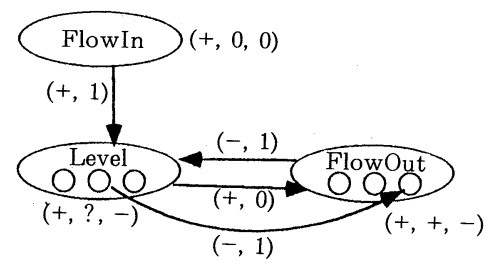

Fig. 3 Conflict between two variables

ここで, FlowInの0 階の+の作用と, FlowOutの 0 階の+の負の作用が Level の1階への作用で競合し， が発生する。しかし，FlowOutの+は1階の+からの 動的伝播により発生したものとすると， 0 点を通過した 直後の+であり, さらに増加を続けることでFlowIn の+とバランスし, その時点で Level の 1 階の值は 0 に 変化するはずである．このような変化を実現するのが動 的バランス則である.

\section{(e) 動的バランス則}

ある変数の階数 $n$ に対し; 動的伝播の結果の静的伝 播を行ない $n$ 階の変数值において + と一の入力が競合 するとき（?になるとき）, 次の処理を行なう.
（1）競合する十，一がともに，このステップでの動的伝 播によるものであれば決定不能（?）とする.

(2) $n$ が打ち切り階数のときは, 変数值を変化させずに そのまま終了する.

(3) 同じ変数に対し $n+1$ 階の值を決定する.

（4） $n$ 階の変数值に対し，（3）で決定された $n+1$ 階の 変数值によって, 動的伝播をセットする.

(1) の場合はどちらの值も変化直後の值であり, 值は決 定できず，動的バランス則は働かない，また，(3)にお いて, $n+1$ 階の值を決定する際に再帰的に呼び出しが 発生する場合むある．再帰的に実行された場合は $n+1$ 階と $n$ 階のどちらを先にバランスさせるかで実行結果 は異なる場合がある，実際には，ここでどちらかを選ん で実行することになるが，後に述べるネットワークの一 貫性により実行順序が一意に定まる場合あある.

これまでの規則を用いた定性シミュレーションの実行 のアルゴリズムを Fig. 4 に示す. また, Fig. 2 (2) の ネットワークに対する実行例を次に示す。ただし，初期 条件としては, FlowIn $=(+, 0,0)$ を与えた.

step 1

rule

$$
\begin{aligned}
& \text { FlowIn }(+, 0,0) \\
& \text { Level }(0,+, 0) \\
& \text { Set Level (0)-DP }
\end{aligned}
$$$$
\text { (a) (d) (2) }
$$

Set Level (1)-Balance-DP

step 2

$$
\begin{array}{ll}
\text { Level } \quad(+, 0,-) \text { Execute }(11)(\mathrm{b}) \\
\text { FlowOut }(+, 0,-) & \text { (a) } \\
\text { Level } \quad(+, 0,0) & \text { (a) } \\
\text { FlowOut }(+, 0,0) & \text { (a) }
\end{array}
$$

ただし，DPは動的伝播，Balance は動的バランスの 発生を表わし, ruleの欄は值変化あるいは動的伝播の 発生に用いられたルールが示されている．この变数の変 化は， 2 階の値までみても実際の值変化に適合している. また，この例は平方根という非線型要素を含むものであ るが, 非線型要素が含まれる場合でも, 単純な収束を行 なうあのなどは検出できる場合がある，今回扱っている 感度解析としての定性シミュレーションでは外乱が収束 するかなどの判定が多く, 収束の検出が可能なことは重 


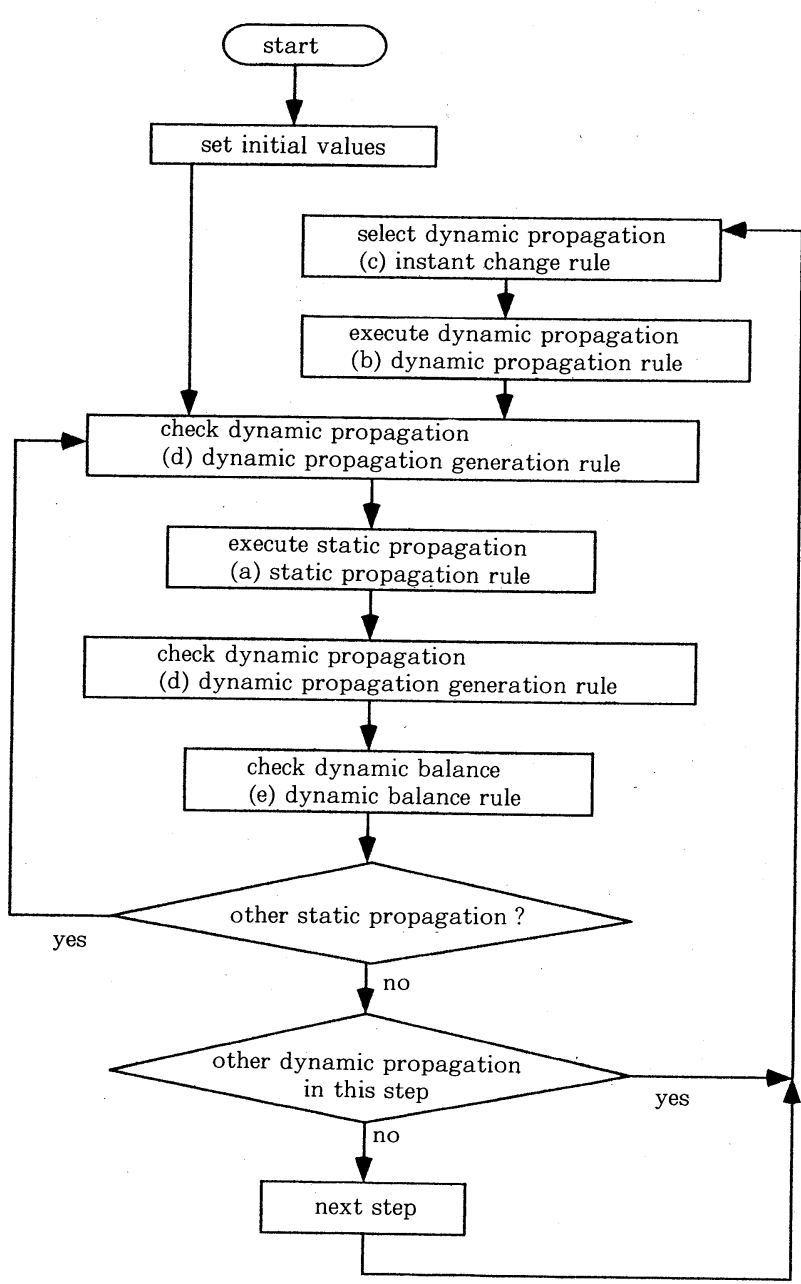

Fig. 4 Qualitative simulation algolithm

値において，すべての入力の定性值としての和 が, その変数の定性值亡なりうる時, $n$ 階の入 力の一貫性が満たされるとする.

定性值の和は, 基本的には Table 1 により決 定されるが，その值が?にになる場合はごの定性 值にもマッチ可能なため，いずれの值でも一貫 性は満たされる. また, $n$ 階の変数值に対して, $n+1$ 階以上の階数差の入力アークが存在する ときは, そのアークからの入力は評価できない ため，その階数での一貫性は定義されない，た とえば 2 階の入力アークをもつ変数においては 1 階と 0 階の入力の一貫性は定義されず， 2 階 以上の值のみに定義される.

入力の一貫性に関しては, 次の規則が成り立 ว.

\section{（f） 伝播の一貫性}

ある変数の $n$ 階の值において伝播（動的伝 播, 静的伝播) が発生するには, 次の条件のい ずれかが満たされる必要がある.

(1) 注目する伝播による $n$ 階の変数值の変化 が, その変数の $n$ 階の入力の一貫性と, その 変数から出力されるアークに結合された変数に おける入力の一貫性を満たしている.

（2）注目する伝播による $n$ 階の変数值の変化 を静的伝播させることにより，ネットワーク全 体で変数の一貫性が満たされる.

（ただし，（1），(2）とも一貫性が定義される階 数のみで評価する.)

(1) が満たされる場合は, その変数における伝 播後の值において一貫性が満たされる状態であ る. Fig. 5 (1) では $A$ の 0 階の值が 0 から+

要となる.

\section{4. 伝播の実行の制限}

これまで述べてきた規則のみでシミュレーションを実 行すると, 物理的に起こりえない定性值の組み合わせが 発生する. 定性方程式に基づく定性シミュレーションで は定性方程式を拘束条件として，そのような解を排除し ている．本章では定性ネットワーク上での拘束条件とな る伝播の一貫性について述べる.

\section{1 伝播の一貫性}

定性方程式における式の拘束条件は, 定性ネットワー クでは変数への入力アークに対する拘束条件となる.こ の拘束条件を入力の一貫性之呼び次のように定義する.

\section{【定義 1】入力の一貫性}

$n$ 階以下の階数差の入力アークを持つ変数の $n$ 階の に変化しても一貫性は満たされている. それに対して, (2) の場合は結合された複数の変数が同時に変化するこ とで, 一貫性が満たされる場合であり，それを静的伝播 により実現する．静的伝播が行なわれる前の状態は中間 的な遷移状態であり，物理的には許されない状態であ る. Fig. 5 (2) では $A$ の值が+から 0 に変化すると $B$ の入力の一貫性が満たされなくなる. そのため変化後の 值 0 を静的伝播させることにより $B$ の值も変化させる. deKleer ${ }^{3)}$ の方法では, 時間変化はあらかじめ作成され

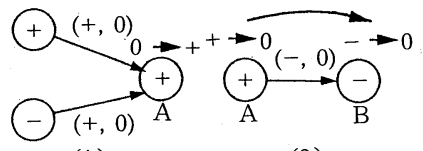

(1)

(2)

Fig. 5 Consistent dynamic propagations 
た矛盾のない変数の組の間で発生するが, 本論文で述べ る方法では，伝播の過程では矛盾状態を許し，静的伝播 により矛盾を解消するという方法を用いている.

伝播の一貫性規則 $(\mathrm{f}-2)$ では, 他の变数で同時に発 生する動的伝播による变化を静的伝播を用いて表わすた め, その静的伝播による変化が, 伝播された变数におけ る動的伝播に対応する必要がある。このことを定性ネッ トワーク上の条件に置き換えると, 次のようになる.

\section{（g）変化方向の同一性}

動的伝播により発生した, 变数 $A$ における $n$ 階の值 の変化を, アークで結合された変数 $B$ の $m$ 階の值に静 的伝播させるには次の条件が満たされなければならない.

(1) アークの作用が+の時

$A$ の $n+1$ 階の值が $B$ の $m+1$ 階の值の等しい.

(2) アークの作用がーの時

$A$ の $n+1$ 階の値と $B$ の $m+1$ 階の值の符号が互い に逆.

(3) アークの作用が? の時

$B$ の $m+1$ 階の值が 0 以外

（4）アークの作用が $++(--)$ の時

$A$ の $n+1$ 階の值の絶対値 (負の絶対値) が $B$ の $m+$ 1 階の值に等しい.

または，変数 $B$ の $m+1$ 階の值が?である.

Fig. 6 では，この規則を用いて $A$ の変化を伝播可能な 変数とそうでないものを示している．ただし， $m$ が打 ち切り階数の場合は, 変化方向を決定不能なため, いつ でも伝播可能とする。

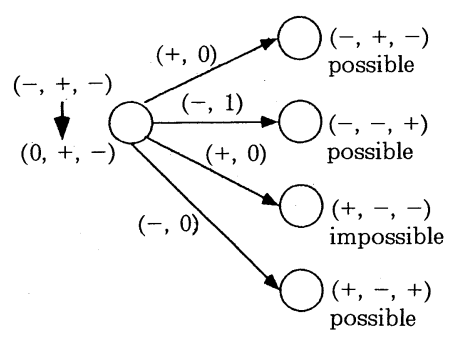

Fig. 6 Possible static propagations

また, 同じく動的伝播による变化は連続した值変化で あることから，次の規則が成り立つ。

\section{(h) 連続性規則}

ある变数における動的伝播の実行に伴う静的伝播によ り, 他の変数に抢いて不連続な変化が発生してはならな い. 不連続な変化とは，変数の值が+から一， あるいは 一から+へ，0 を通過せずに変化するすのである. deKleer ${ }^{3)}$ の方法では動的伝播に伴う変数とその微分值. の連続性に注目しているが, 定性ネットワークでは状態
遷移は一つの動的伝播とそれに伴う静的伝播から発生す るため, 静的伝播の連続性にも注目する必要がある. た だし, 打ち切り階数の值に対しては変化方向の同一性と 同様に連続性は考慮しない.これは打ち切り階数の值に 対しては動的伝播が定義できないためである，また， (h) から次の規則が導かれる.

\section{( $\mathrm{h}-1)$ 連続性規則 (2)}

変数 $A$ で発生した動的伝播に伴う静的伝播で, 変数 $B$ に不連続な変化が発生するとき, 変数 $B$ に扔ける動 的伝播が変数 $A$ のあのより先行する. 乙の規則は不連 続な変化が発生した場合に，その伝播を行なうための前 提条件となる伝播を決定できる.

また，ある变数における動的伝播に対して，(g)，(h) が満たされ静的伝播が可能な状態にあっても, 静的伝播 を行なわなくても伝播の一貫性が満たされている場合は, その静的伝播は必要としない. このような場合はその変 数における動的伝播がそのまま継続することになる。つ まり, 動的伝播と静的伝播の関係は次の三つが考えられ る.

（1）動的伝播の結果が静的伝播可能であるが，必ずしあ 必要としない.

（2）動的伝播の結果か清争的伝播可能で, かつ必要とする.

（3）動的伝播の結果は静的伝播不可能である.

実際の定性シミュレーションの際には，この三つの場合 に応じて, 処理を行なう必要があり, その場合分けをこ れまで述べてきた (f)-(h) の規則で行なうことが可能 である.

これまで述べてきた規則は, Fig. 4 のアルゴリズム の中で動的伝播および静的伝播を実行する際に用いられ, それに関連する規則を満たす伝播のみが実行される.

\section{2 変数の結合とブロック化}

実際の定性ネットワークの作成には, 各コンポネント （パイプ，タンク等）ごとにモデルを作成し，それらの 結合により全体を構築する枠組みを与えている．そのた めに一つの值を示す变数が結合部において分割される場 合があり，変数の一貫性を見直す必要がある．たとえば Fig. 7 のような場合を考えてみる. 変数の一貫性のみ を考えた場合, 变数 $A$ は+のみ, 変数 $B$ は一のみの入 力であり,一貫性は満たさない. しかし，実際には変数 $A, B$ は双方向アークにより結合されており,一つの変 数が二つに分割されたものであり， $A, B$ 全体に対して

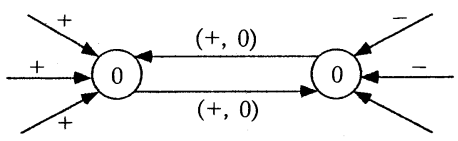

Fig. 7 Connected variables 

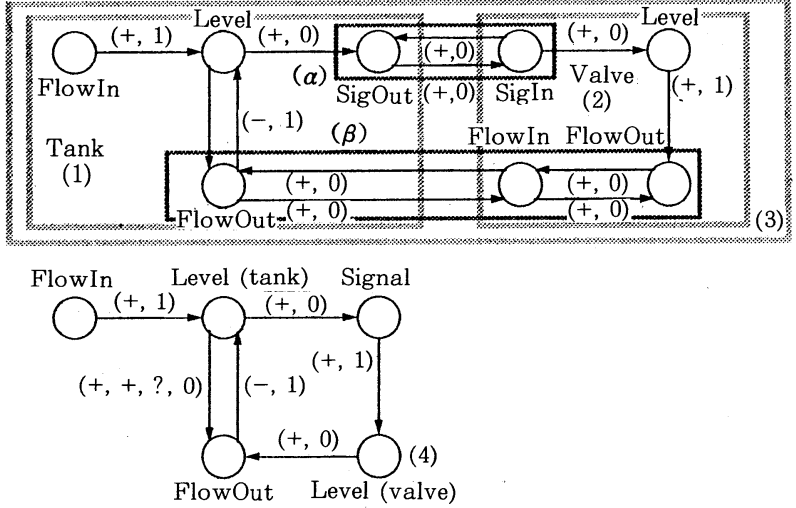

Fig. 8 Variable block configuration

+, 一が入力されていると考えられる. 今回作成したシ ステムにおいてはコンポネント間の結合は，このような 双方向アークを用いて変数を結合することで実現してい る，そのため，双方向アークを用いた結合については， 一貫性の定義を見直す必要がある．そのために変数ブロッ クという概念を導入する. 次に变数ブロックの定義を示 す.

\section{【定義 2】変数ブロック}

互いに同じ作用を持っ双方向アークにより結合された 変数の集合を変数ブロックとして定義する.

さらに，変数ブロックに基づく伝播規則を加える.

\section{（i ）変数ブロックに基づく伝播規則}

変数ブロックによりブロック化されている変数に対し ては，おのおのの変数を独立に扱わずに，変数ブロック を変数とみて $(\mathrm{a}) \sim(\mathrm{h})$ の規則を適用する. Fig. 8 (1), (2) のように記述されたタンクとバルブのコンポネント を結合し，(3) のモデルが得られたとする，乙のとき $(\alpha),(\beta)$ で示された部分は変数ブロックとなる. このモ デルは，乙れらを一つの変数とした (4) のモデルと同等 に扱われる.

変数ブロックの考え方を取り入れることで，コンポネ ントの結合時にも一貫性の保たれたシミュレーションを 可能とした。

\section{5. ほかの定性シミュレーションアルゴリズ ムとの比較}

この章では, 本論文のアルゴリズムを Kuipers, deKleer の方法と比較する

(1) deKleer の方法 ${ }^{2), 3)}$ との比較

deKleer の方法では，定性方程式をモデルとして用 いている. シミュレーションにおいては，状態間の時間 的な変化を状態遷移として求め，その状態に対し定性方
程式上で矛盾のない変数の組み合わせである解 粎から，物理的に正当なものを選ぶことで，変 数の值を決定したり，物理的に起こり得ない状 態遷移を省いたりする，そのため，大規模なシ ステムを対象にすると，状態の数が膨大になり 解析が困難になると考えられる。.また，変数の 数も多くなるため, 状態に対する解釈も増えて しまい，処理が複雑になる，本論文のアルゴリ ズムは，外乱をただ単に前向きに伝播させるこ とでシミュレーションを行なうことで処理を簡 単化しようというあのである。そそのために，伝 播を動的伝播と静的伝播に分け，動的伝播で状 態遷移を発生させ，静的伝播でネットワークの 一貫性を保証するという方法をとっている。こ の一貫性を調べるため規則は基本的には deKleer の あのと同じであり，定性ネットワーク上のルールとして 拡張されている．また，動的バランス則を用いることで 前向きの伝播で発生する決定不能の変数を減少させてい る.

\section{(2) Kuipers ${ }^{4)}$ の方法との比較}

Kuipers の方法では，定性方程式から得られるネッ トワークモデルを用い，ネットワーク上での值伝播と変 数值の境界值への変化を基にシミュレーションを進める. この方法は，境界值に対する变数值の相対的な值とその 変化方向に注目し，変数間に定義された作用に従ってそ れらを伝播するというあのである．この方法では，前向 きの伝播を基にシミュレーションを進めるが，境界值の 設定を行なうなど複雑な規則を用いている，本論文の方 法は，Kuipers と同じく前向きに探索を行なうが，境 界值が固定 (0) で処理も簡単であり，(d) 動的伝播発生 の決定則を用いて独立な動的伝播しか調べないため，探 索の大きさが小さくてすむ.

\section{6. 定性シミュレーション実行例}

本節では，これまで述べた規則を用いて定性シミュレ ーションを行なった例を示す。

例としては，減衰振動を行なうバネを用いる，その方 程式は次の式で与えられる。

$$
m \cdot \frac{d^{2} x}{d t^{2}}+a \cdot \frac{d x}{d t}+b \cdot x=0
$$

ただし，定数 $m, a, b$ はすべて正とする．これに対す る定性ネットワークを Fig. 9 (1) に示す.また，説明の 都合上，各階数ごとに変数を分解したものを Fig. 9 (2) に示す．この場合は，アークの作用はすべてーである. ただし，計算には 4 階までの微分值を用い 3 階までの定 性值を有効とする。初期状態として $x=(+, 0,0,0)$ を 


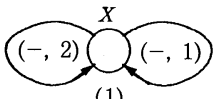

(1)

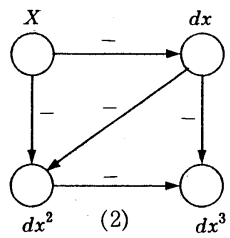

Fig. 9 Example for mass spring system with friction
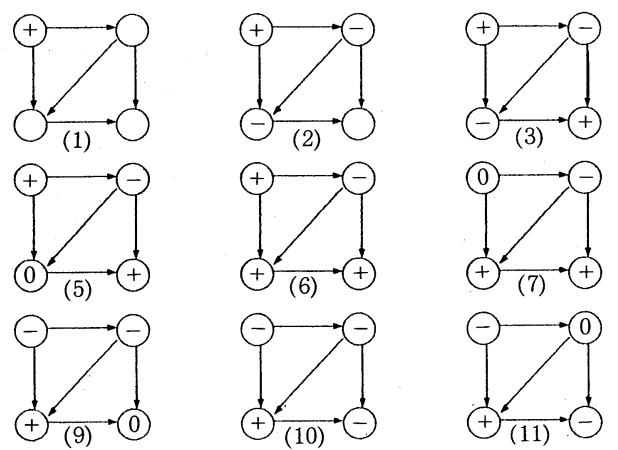

Fig. 10 Trace of a sample execution (1)
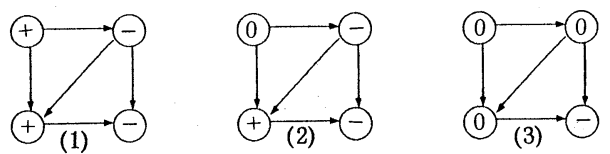

Fig. 11 Trace of a sample of execution (2)

与え，実行したトレースを Fig. 10 に示す．ただし，各 状態間のアークに与えられたアルファベットはその過程 で用いた規則を示す．まず，第 1 ステップでの静的伝播 により，Fig. 10 (3) の状態になる. 第 2 ステップでは 動的伝播が実行されるが，まず 1 階から 0 階への動的伝 播を調べると実行後の結果は Fig. 10 (4) になり 2 階の 微分值の入力に矛盾が生じ, また実行結果の静的伝播屯 変化方向の不一致より無理で, 実行不可能である. つぎ に 3 階から 2 階への作用を調べると, Fig. 10 (5) にな り,すべての入力で一貫性が満たされるため実行可能で ある. 実行結果の静的伝播は变化方向が不一致により, 実行されない. 次には 0 の瞬時性からこの 0 が+に変化 する.この場合は, 一貫性は満たされており問題ない. さらに，この值は 3 階の值に静的伝播され，バランス則 により 3 階の值に対し 0 への動的伝播がセットされる. その後は, Fig. 10 に示すように動的伝播が継続される. Fig. 10 の最終状態は (3) と比べると符号がすべて逆で あり, 同様の伝播で (3) の状態に復㸝し, 振動状態が発 生する.また, Fig. 10 の（6）の状態においては 3 階の
值 + む 0 から-に変化可能でこの変化により変数值は $(+,-,+, ，-)$ となる (Fig.11 (1)). この場合は, 1 階から 0 階の值への動的伝播が発生し, 0 階の值が 0 と なり,この状態でネットワークの一貫性が満たされてい る (Fig.11 (2)). ここで, この值の静的伝播について 調べると静的伝播は可能で, 静的伝播を行なうと, Fig. 11 (3)，(4)になり，すべての值が 0 に収束する.これ は, このすべての值が同時に 0 に変化することを表わし ている. ただし，この变化は無限時間のステップを要す
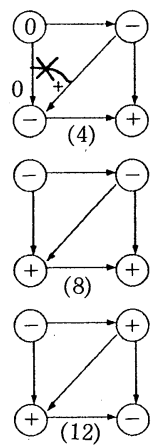

(12)

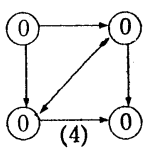

る.なおここで述べたこの二つの変化 は, 双方とあ正当なむのであり, 定性值 のみでは片方を選択するのは不可能であ る.このような場合に, 今回作成したシ ステムでは作用の優先度や定性値のオー ダなどを用いて決定している.

\section{7. 結 言}

本論文では, 定性ネットワークによる 物理系の定性モデルの作成とその実行ア ルゴリズムについて述べた. 次にその特 徵を示す。

1. 定性ネットワークによるモデル記述 により, 物理系の構造から容易に定性モ デルを得ることができる.

2. 新たに開発したネットワーク上での 定性シミュレーションのアルゴリズムに より, 高速に物理系全体の一貫性まで考 えた正確な定性シミュレーションが可能である.

3. 対象が非線形の場合です, 線形要素と一部の非線形 要素で記述可能な範囲でモデルを作成し, シミュレーショ ンを行なうことが可能で, 外乱に対する収束可能性など を調べることができる．

このアルゴリズムでは, 動的伝播の実行の可能性とそ れに伴う静的伝播の実行について判定を行なうが, 実際 にはある時点において実行可能な伝播は数多く存在する. ネットワークの一貫性という意味では, これらの伝播は すべて物理的に実行可能である.しかし，すべての場合 に関して実行すると非常に多くのパスが存在するため, それらの中から実行する伝播を選択するメカニズムが必 要になる. 今回, 作成したシステムでは変数, アークな ぞに優先度を定義し, 優先度の高いものから実行させる ようにした。 しかし, 実際には優先度をモデル作成時に 決定するのは難しく, なんらかの方法で意味のある伝播 の実行を選択する方法が必要であると考えられる.

また，この方法ではネットワーク結合上での変数間の 一貫性は調べているが, 位相的な一貫性は調べていない。 
たとえば 2 次の系で位相的な情報を扱うには，位相面上 での変数値の挙動を考える必要がある.これまで位相曲 線の交わりを防ぐなどの処理を考えた方法はあるが5),6), 位相曲線の漸近的なふるまいなどを扱う方法は考えられ ていない，この場合は, 定性值をどのように位相面の情 報として扱うかが問題になり, 今後の研究の課題である.

\section{参 考 文 献}

1) Y. Ishida : An Application of Qualitative Reasoning to Process Diagnosis : Rule Generation by Qualitative Simulation ; 4 th IEEE Conf. on AI App., pp. 124 129 (1988)

2) J. deKleer and J.S. Brown : A Qualitative Physics Based on Confluence ; Artificial Intelligence, Vol. 124, pp. $7 \sim 83$ (1984)

3) J. deKleer and D. G. Boblow : Qualitative Reasoning with Higer-Order Derivatives ; Proceedings of AAAI84, pp. 86 91(1984)

4) B. Kuipers : Commonsence Reasoning about Causality : Deriving Behavior from Structure ; Artificial. Intelligence, Vol. 124, pp.169 203 (1984)

5) P. Struss : Global Filters for Qualitative Behaviors ; Proceedings of AAAI-88, pp. 275 276 (1988)

6) W. W. Lee and B. J. Kuipers : Non-Intersection Trajectories in Qualitative Phase Space: A Global Conetraint for Qualitative Simulation ; Proceedings of AAAI-88, pp. 286 290 (1988) 